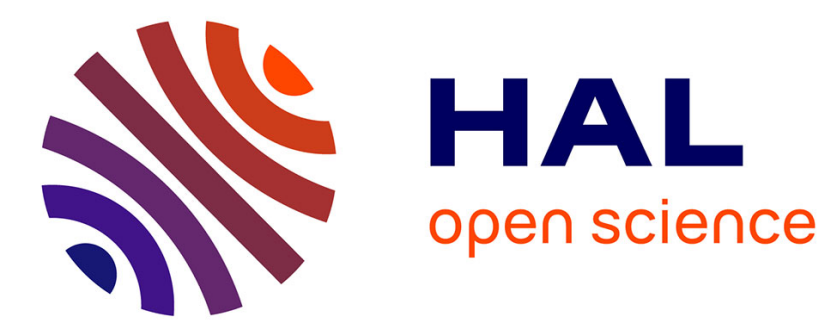

\title{
Use of complex physiological traits as ecotoxicological biomarkers in tropical freshwater fishes
}

\author{
Diana A Monteiro, Ana L Kalinin, F Tadeu Rantin, David Mckenzie
}

\section{To cite this version:}

Diana A Monteiro, Ana L Kalinin, F Tadeu Rantin, David Mckenzie. Use of complex physiological traits as ecotoxicological biomarkers in tropical freshwater fishes. Journal of Experimental Zoology Part A: Ecological and Integrative Physiology, 2021, 335 (9-10), pp.745 - 760. 10.1002/jez.2540 . hal-03438296

\section{HAL Id: hal-03438296 \\ https://hal.science/hal-03438296}

Submitted on 26 Nov 2021

HAL is a multi-disciplinary open access archive for the deposit and dissemination of scientific research documents, whether they are published or not. The documents may come from teaching and research institutions in France or abroad, or from public or private research centers.
L'archive ouverte pluridisciplinaire HAL, est destinée au dépôt et à la diffusion de documents scientifiques de niveau recherche, publiés ou non, émanant des établissements d'enseignement et de recherche français ou étrangers, des laboratoires publics ou privés. 
1 Use of complex physiological traits as ecotoxicological biomarkers in tropical

2 freshwater fishes

3

4 Diana A. Monteiro ${ }^{1}$, Ana L. Kalinin ${ }^{1}$, F. Tadeu Rantin ${ }^{1}$, David J. McKenzie ${ }^{1,2^{*}}$

5

6 1. Department of Physiological Sciences, Federal University of São Carlos (UFSCar),

7 13565-905, São Carlos, São Paulo, Brazil.

8 2. UMR Marbec, Univ. Montpellier, CNRS, IRD, Ifremer, 34095 Montpellier, France 9

Running title: Physiological biomarkers in tropical freshwater fishes

*Author to whom correspondence should be addressed: david.mckenzie@cnrs.fr 


\section{Abstract}

We review the use of complex physiological traits, of tolerance and performance, as biomarkers of the toxicological effects of contaminants in subtropical and tropical freshwater fishes. Such traits are growing in relevance due to climate change, as exposure to contaminants may influence the capacity of fishes to tolerate and perform in an increasingly stressful environment. We review the evidence that the critical oxygen level, a measure of hypoxia tolerance, provides a valuable biomarker of impacts of diverse classes of contaminants. When coupled with measures of cardiorespiratory variables, it can provide insight into mechanisms of toxicity. The critical thermal maximum, a simple measure of tolerance of acute warming, also provides a valuable biomarker despite a lack of understanding of its mechanistic basis. Its relative ease of application renders it useful in rapid evaluation of multiple species, and in understanding how the severity of contaminant impacts depends upon prevailing environmental temperature. The critical swimming speed is a measure of exercise performance that is widely used as a biomarker in temperate species but very few studies have been performed on subtropical or tropical fishes. Overall, the review serves to highlight a critical lack of knowledge for subtropical and tropical freshwater fishes. There is a real need to expand the knowledge base and to use physiological biomarkers in support of decision making to manage tropical freshwater fish populations and their habitats, which sustain rich biodiversity but are under relentless anthropogenic pressure. Key-words:

Biomarker, critical oxygen level, critical swimming speed, critical thermal maximum, ecotoxicology, hypoxia, warming. 
Introduction

Freshwater ecosystems, and their resident fish populations, are particularly at risk from negative impacts of anthropogenic global change (Mason, 2002; Costa and Barletta, 2016; Higgins et al., 2021). Freshwater ecosystems are suffering relentless contamination with a bewildering diversity of chemical hazards and toxic substances such as agricultural chemicals; industrial solvents, surfactants and flame-retardants; metals, and pharmaceutical products, among many other pollutants (Stauffer, 1998; Mason, 2002; Rantin et al., 2020). These enter waterways directly from treated and untreated industrial, agricultural and domestic wastewaters, from run-off and atmospheric deposition (including spray drift) and indirectly from leaching (Holt, 2000). The diversity of contaminants and their potential toxic effects on freshwater fishes grow incessantly (e.g. Jobling and Tyler, 2003; Pérez-Parada et al., 2018; Wagner and Lambert, 2018).

In aquatic organisms, biomarkers are used to provide early warning signals of exposure or effects of specific pollutants or pollutant classes (Peakall, 1994; van der Oost et al., 2003). They are defined, in a broad sense, as any biological response by an organism to exposure to environmental chemicals, or to their toxic effects. The term is most commonly used to refer to measurements in body fluids, cells or tissues, which are indicative of bioaccumulation of toxic chemicals, biochemical and cellular modifications provoked by specific toxicants (van der Oost et al., 2003; Kroon et al., 2017) but would also be pertinent for other responses, for example behavioural alterations (Little and Finger, 1990; Saaristo et al., 2018).

For fishes it has long been recognized that complex traits of whole animal physiology, especially traits of functional integrity and energetics, are valuable indicators of sublethal toxicological impacts of contaminants (Brett, 1958; Cairns, 1966; Sprague, 1971; McKenzie et al., 2007). They have direct ecological relevance because the survival of an organism under stressful conditions depends on its ability to balance energy demand and energy supply (Calow and Forbes, 1998), and complex traits of functional integrity and energetics will influence how effectively a fish can achieve this, and cope with the conditions and the demands of life in their habitat (Cairns, 1966; Sprague, 1971; McKenzie et al., 2007). Physiological traits are particularly useful as components of an approach combining multiple biomarkers, which can capture different response kinetics and toxicological impacts of contaminants, especially in natural environments where contaminants occur as complex mixtures (Hook et al., 2014; Dalzochio et al., 2016).

Traits of tolerance of environmental stressors, such as hypoxia or warming, were first proposed as biomarkers 50 years ago (Cairns, 1971; Sprague, 1971). They 
are now gaining increased ecological relevance because of ongoing climate change, which is predicted to make freshwater environments increasingly physiologically challenging for fishes (Diaz and Breitburg, 2009; Noyes et al., 2009; Stillman, 2019). Aquatic hypoxia is expected to be ever more common as a stressor, including an increased frequency of severe hypoxic episodes (Diaz and Breitburg, 2009; Costa and Barletta, 2016). The same is true of warming where, beyond gradual rises in seasonal mean temperatures, an increased frequency, intensity and duration of seasonal heatwaves is projected to be a major source of environmental stress for fauna globally (Williams et al., 2016; Stillman, 2019). The extent to which contaminants can influence tolerance of hypoxia or warming may, therefore, be determinants of the capacity of fish populations to persist in certain habitats (Noyes et al., 2009; Noyes and Lema, 2015; Khursigara et al., 2019; Isaza, 2020). The capacity to perform exercise is also a valuable and ecologically relevant biomarker of sub-lethal toxic effects of pollutants on fishes, because activities such as foraging, escaping predators, protecting territory, and migration, all depend upon swimming (Brett, 1958; Cairns, 1966; Beamish, 1978; McKenzie et al., 2007; Domenici, 2010; Domenici and Hale, 2019). One particular advantage, of complex physiological traits of tolerance and performance as biomarkers, is that they integrate the function of multiple underlying physiological systems, and can provide insight into why fish fail to colonize some polluted habitats (McKenzie et al., 2007). It is therefore possible to investigate what causes impairment of tolerance or performance, to gain valuable understanding of the impacts of contaminants on fish health and populations (e.g. Beaumont et al., 1995, 2000; Tierney et al., 2007; Thomaz et al., 2009; Gomez Isaza et al., 2020), which is particularly useful within programmes of ecological risk assessment.

We review knowledge on the application of physiological biomarkers in subtropical and tropical fish species, which we take to mean those that can occupy habitats where average monthly temperatures do not fall below $18^{\circ} \mathrm{C}$. Many subtropical and tropical freshwater ecosystems suffer from pollution and limited environmental regulation, so exposure to contaminants represents a serious hazard to population health of resident fishes (Langiano et al., 2008; Cazenave et al., 2009; BrazMota et al., 2015; Beltrão et al., 2019; Barreto et al., 2020). At the same time, tropical ecosystems are relatively poorly studied in terms of ecotoxicology, despite harbouring important resources in terms of biodiversity (Lacher and Goldstein, 1997; Daam and Van Den Brink, 2010; Wang et al., 2019). They can also be naturally subject to stressful hypoxic and warming events, especially because many have seasonal variations in rainfall that severely modify the volume and connectivity of habitats. We consider studies that have used the critical oxygen level $\left(\mathrm{O}_{2 \text { crit }}\right)$ as a biomarker. For 
these studies, we pay particular attention to how changes in $\mathrm{O}_{2 \text { crit }}$ caused by contaminant exposure are linked to elements of cardiorespiratory physiology and performance, as these are core components of whole animal tolerance (Driedzic and Gesser, 1994; Gamperl and Driedzic, 2009). We then consider studies that have used traits of thermal tolerance as biomarkers, in particular the critical thermal maximum $\left(C T_{\max }\right)$. Finally, we review the few studies that have used critical swimming speed $\left(\mathrm{U}_{\text {crit }}\right)$ as a biomarker.

\section{Effects of contaminants on tolerance of hypoxia}

Hypoxic events can be very frequent in subtropical and tropical freshwater ecosystems, with dissolved oxygen (DO) fluctuations of different duration and magnitude, diurnally, spatially, and seasonally (Almeida-Val et al., 2006). Although fluctuating levels of DO can be a natural phenomenon, hypoxia caused by eutrophication and pollution is one of the most pressing and critical water problems in the world (Pollock et al., 2007). Hypoxia and contaminant exposure often co-occur in aquatic environments but their interactions remain poorly studied (Monteiro et al., 2020). There is evidence that co-exposures to hypoxia and polycyclic aromatic hydrocarbon mixtures caused several disorders in fishes, such as altered growth and sexual differentiation, reduced reproductive capacity, and developmental toxicity (Matson et al. 2008; Di Giulio and Clark, 2015; Mu et al., 2017). Rahman et al. (2018) demonstrated that co-exposure to hypoxia and polychlorinated biphenyl reduced biotransformation of organic xenobiotics by monooxygenase enzyme cytochrome P450-1A (CYP1A), but markedly augmented hepatic endothelial nitric oxide synthase (eNOS) and interleukin-1 $\beta$ (IL-1 $\beta$ ) mRNA levels, and protein carbonyl (PC) contents.

Hypoxia survival requires a well-coordinated response to either secure more $\mathrm{O}_{2}$ from the depleted environment or to protect against the metabolic consequences of low $\mathrm{O}_{2}$ levels at the mitochondria, which limit aerobic ATP production (Regan et al., 2017; Richards, 2019). The critical oxygen level $\left(\mathrm{O}_{2 \text { crit }}\right)$ is widely used as a quantifiable trait of hypoxia tolerance in fishes. It represents the minimum water oxygen level required to sustain standard metabolic rate (SMR, the basal metabolic rate of an ectotherm at their acclimation temperature) (Claireaux and Chabot, 2016; Rogers et al., 2016). It is determined by plotting rates of oxygen uptake $\left(\mathrm{MO}_{2}\right)$ against water $\mathrm{O}_{2}$ tension $(\mathrm{kPa})$, to identify the point at which $\mathrm{MO}_{2}$ falls below SMR, and becomes directly dependent upon

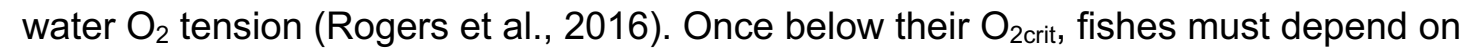
anaerobic energy metabolism and basal functions can be compromised (Pörtner, 2010). If the hypoxic conditions worsen and persist, the combination of hypoxic severity and accumulation of metabolic products can threaten survival (Claireaux and Chabot, 
2016). Although the ecological significance of the $\mathrm{O}_{2 \text { crit }}$ threshold has been debated (Wood, 2018; Regan et al., 2019; Ultsch and Regan, 2019), it varies among species in a manner that is consistent with their overall hypoxia sensitivity, being lower in more tolerant species (Rogers et al., 2016). A low $\mathrm{O}_{2 \text { crit }}$ value indicates a higher capacity for $\mathrm{O}_{2}$ extraction by the gills and $\mathrm{O}_{2}$ delivery to the tissues as $\mathrm{O}_{2}$ availability declines, indicating a greater hypoxia tolerance (Mandic et al., 2009).

Figure 1 shows data for one species, matrinxã Brycon amazonicus, where sublethal exposures to various contaminants all increased $\mathrm{O}_{2 \text { crit }}$ values. The degree of physiological plasticity for hypoxia tolerance is a key determinant of species performance (Rogers et al., 2016). This was associated with various impacts of the contaminants on $\mathrm{MO}_{2}$ during graded hypoxia (Table 1). This is shown in more detail for the matrinxã, where contaminants had various effects on $\mathrm{O}_{2}$ uptake such as increases and decreases in $\mathrm{MO}_{2}$ during normoxia (for Roundup Original ${ }^{\circledR}$ and Roundup Transorb $^{\circledR}$, respectively) and/or early decline in $\mathrm{MO}_{2}$ during graded hypoxia for all pollutants (Figure 2). All these effects had the consequence of impairing the capacity of the species to oxyregulate. According to McRae et al. (2018) metabolic rate is, itself, a useful integrated measurement of toxicological impact because it is a measure of energy resource associated with multiple sublethal processes and ecologically important endpoints such as reproduction, growth and survival.

The exposure to various contaminants markedly increased $\mathrm{O}_{2 \text { crit, and therefore }}$ reduced tolerance of hypoxia, in four species of tropical fishes, including hypoxiatolerant fish species such as Nile tilapia Oreochromis niloticus and trahira Hoplias malabaricus (Table 1). These data clearly indicate that exposure to contaminants may reduce survival chances of many species of fishes in tropical hypoxic environments. Table 1 also summarises how different pollutants can have a diverse array of effects on both ventilatory and cardiac activity in normoxia, and how such activity can be affected at given levels of hypoxia.

Oxyregulation is achieved by reflex cardiorespiratory responses that aim to sustain oxygen uptake and delivery, and possibly protect vital organs such as the heart. There is a profound hyperventilation, involving increases in gill ventilation volume $(\dot{V} G)$ achieved through increased respiratory frequency $\left(f_{\mathrm{R}}\right)$ and amplitude, and a bradycardia (Farrell, 2007; Perry et al., 2009; Joyce et al., 2016; Rantin et al., 2020). The hyperventilation increases $\mathrm{O}_{2}$ transport to the site of gas exchange (Bergsson et al., 2019). Enhancements in $\dot{V} G$ are required to maintain a constant $\mathrm{MO}_{2}$, which implies that fish survival in hypoxic environments can be compromised if the ability to increase $\dot{V} G$ is affected (Martins et al., 2011). Pollutants can, indeed, impair the ability to 
increase $f_{\mathrm{R}}$ and $\dot{V} G$ in response to hypoxia, impairing the regulation of metabolic rate.

190 For example, the lower $f_{\mathrm{R}}$ induced by acute exposure to the organophosphate

191 trichlorfon in Nile tilapia Oreochromis niloticus, both in normoxia and hypoxia, impaired

192 gill ventilation and compromised the hyperventilatory response in severe hypoxia

193 (Thomaz et al., 2009). The same response pattern was observed in trahira after

194 subchronic and trophic exposure to mercury chloride (Monteiro et al., 2013). In

195 matrinxã, increases of $f_{\mathrm{R}}$ and $\dot{V} G$ in response to hypoxia were significantly reduced

196 after acute exposure to the emerging contaminant triclosan, an antimicrobial agent

197 widely used in personal care products. In normoxia, triclosan had caused an increased

$198 f_{\mathrm{R}}$ with concomitant decreased $\dot{V} G$ (Martins, 2018). Under hypoxia, $\dot{V} G$ values were also

199 considerably lower in Nile tilapia $48 \mathrm{~h}$ after intraperitoneal injection of mycrocystin-LR

200 (Martins et al., 2011) and in matrinxã acutely exposed to glyphosate-based herbicides

201 Roundup WG ${ }^{\circledR}$ and Roundup Transorb ${ }^{\circledR}$ (Anelli Jr., 2010), probably due to alterations of

202 homeostatic reflexes that impaired respiratory responses to hypoxia, due to unknown

203 toxic mechanisms. All these effects described above and presented in Table 1 can

204 reduce the ability of tropical fish to maintain a constant $\mathrm{O}_{2}$ uptake when they encounter

205 hypoxia in contaminated environments

206 Organophosphate (OP) pesticides, mercury chloride, triclosan, and glyphosate-

207 based herbicides inhibit acetylcholinesterase activity resulting in paralysis, mainly of

208 the fins and respiratory muscles, uncoordinated movements, seizures, and even

209 central depression of respiration (Suresh et al., 1992; Sancho et al., 1998; Antonijevic

210 and Stojiljkovic, 2007; Thomaz et al., 2009; Modesto and Martinez, 2010; Menéndez-

211 Helman et al., 2012; Pullaguri et al., 2021). Furthermore, contaminants such as

212 microcystins and glyphosate-based herbicides cause oxidative stress and alterations in

213 gill structure and respiratory epithelium (Gupta and Guha, 2006; Shiogiri et al., 2012;

214 Braz-Mota et al., 2015; Martins et al., 2017) which could result in disturbances in

215 respiratory function. Specifically for matrinxã exposed to Roundup Original ${ }^{\circledR}$, Roundup

$216 \mathrm{WG}^{\circledR}$ and Roundup Transorb ${ }^{\circledR}, \dot{V} G$ values were already high in normoxia (Table 1),

217 indicating increased respiratory drive to maintain $\mathrm{O}_{2}$ extraction.

218 On the other hand, contaminants can also induce rises in respiratory frequency

219 and conspicuous increases in gill ventilation, including in hypoxia, which may indicate a

220 desperate attempt to meet tissue oxygen demand. Increased gill ventilation was

221 detected in matrinxã after methyl parathion and Roundup Original ${ }^{\circledR}$ exposure, mainly

222 during hypoxia (Table 1, Olle 2007; Anelli Jr., 2010). Wang et al. (2013) evaluated the

223 ventilatory responses of 3 tropical species, zebrafish Danio rerio, rare minnow

224 Gobiocypris rarus and grass carp Ctenopharyngodon idellus to acute exposure to 4

225 heavy metal ions $\left(\mathrm{Hg}^{2+}, \mathrm{Cu}^{2+}, \mathrm{Cd}^{2+}\right.$, and $\left.\mathrm{Zn}^{2+}\right)$. Ventilatory frequency and amplitude 
increased after exposure to $\mathrm{Hg}^{2+}$ and $\mathrm{Cu}^{2+}$ but markedly decreased with increasing concentrations of $\mathrm{Cd}^{2+}$ and $\mathrm{Zn}^{2+}$. This shows that respiratory activity of fishes is highly sensitive to heavy metal pollution but in complex ways (Wang et al., 2013). Differences in ventilatory responses to hypoxia could also be related to changes in blood $\mathrm{O}_{2}$ carrying capacity (Pereira et al., 2013; Islam et al., 2019), according to the type and concentration of contaminants and the physiology of the target species. In the silver perch Bidyanus bidyanus from Australia, exposure to nitrate caused animals to perform aquatic surface respiration (ASR) at a higher oxygen level during progressive hypoxia (from 19 to $1 \mathrm{kPa}$ ), coupled with increased ventilation frequency. This was linked to lower levels of hemoglobin and hematocrit, indicating reduced blood oxygen carrying capacity (Gomez Isaza et al., 2021a). Fish exposed to pollutants often show hyperplasia and hypertrophy of gill epithelia cells with fusing and thickening of gill lamellae and mucus hypersecretion, which increases the water/blood diffusion distance and impairs $\mathrm{O}_{2}$ uptake, leading to hypoxemia (Schjolden et al., 2007; Sokolova and Lannig, 2008; Bilberg et al., 2010). In traíra, exposure to a single dose of microcystinLR (100 $\mu \mathrm{g} \mathrm{Kg}^{-1}$ of body weight, i.p.) caused hyperventilation coupled with significantly reduced $\mathrm{O}_{2}$ extraction from the ventilatory current under normoxic and hypoxic conditions, which compromised $\mathrm{O}_{2 \text { crit }}$ and was attributed to compromised gill gas transfer (Martins et al., 2019).

Many pollutants (methyl parathion, tricholorfon, Roundup WG ${ }^{\circledR}$, Roundup Transorb $^{\circledR}$, mercury chloride, microcystin) also impaired cardiac activity, causing a bradycardia that then lead to very low heart rates under hypoxic conditions (Table 1). This may indicate direct toxic effects on cardiac myocytes. Several studies have reported decreased myocardial isometric twitch force development in tropical fishes exposed to pollutants (Incardona et al., 2004; Thomaz et al., 2009; de Andrade Waldemarin et al., 2012; Monteiro et al., 2017). Reduced cardiac performance can increase the likelihood of starvation, predation vulnerability, and disease susceptibility (Incardona and Scholz, 2017). Exposure to $1 \mathrm{mg} \mathrm{L}^{-1}$ of copper sulfate for $96 \mathrm{~h}$ caused significant changes in Nile tilapia cardiomyocytes, including decreased myocardial contractility, cellular swelling, mitochondrial swelling, and alterations in mitochondrial inner membranes, which may impair ATP supply (de Andrade Waldemarin et al., 2012). Monteiro et al. (2020) found that cardiac responses to hypoxia were impaired in both matrinxã and traira after exposure to inorganic mercury by different routes (water and diet) and durations (acute and sub-chronic). There were alterations in the rhythm of the cardiac pacemaker such as first-degree atrioventricular block, lengthening of the action potential (AP) plateau, and the development of cardiac arrhythmias and abnormalities (episodes of missing QRS complexes with sequential P waves, 
extrasystoles, negative QRS complex, T wave inversion) (Monteiro et al., 2020). These disruptions of electrical conduction could underly the myocardial dysfunction and increase hypoxia sensitivity by impairing cardiac output (Rantin et al., 1995).

Overall, these findings demonstrate that $\mathrm{O}_{2 \text { crit }}$ is a valuable biomarker of impacts of contaminants in tropical freshwater fishes, irrespective of the ecology and life history characteristics of a given species. In addition, analyses of effects on $\mathrm{MO}_{2}$ and cardiorespiratory variables can improve understanding of the mode of toxic action of some contaminants, which can aid in the environmental risk assessment of aquatic systems. The fact that contaminants can impair hypoxia tolerance may have significant ecological consequences, not just directly influencing survival but potentially also reducing fitness, by impairing the capacity to forage, capture and digest food, with consequences for growth and/or reproductive rates. Nonetheless, the knowledge base is critically limited and should be extended to further species and contaminants.

\section{Effects of contaminants on tolerance of warming}

There are complex interactions between temperature and the toxicity of contaminants in fishes, which depend upon multiple factors that are too extensive to review here (Noyes et al., 2009; Patra et al., 2015). We focus exclusively upon the use of thermal tolerance as a biomarker. In fishes, limits of thermal tolerance are measured using acute thermal ramping protocols, especially the critical thermal (CT) methodology that reveals the threshold temperature which causes loss of equilibrium (LOE). The protocol is simple and defines the temperature where survival is threatened because at LOE the fish cannot escape the conditions (Beitinger and Lutterschmidt, 2011). There are, however, quite major limitations to the critical thermal protocol as an experimental tool (Rezende et al., 2014; Blasco et al., 2020). Notably, the idea that the complexity of thermal tolerance limits can be captured by a single measure is a major oversimplification (Rezende et al., 2014; Rezende and Bozinovic, 2019; Lefevre et al., 2021). There are also methodological issues; particularly that the measured $\mathrm{CT}_{\max }$ depends upon heating rate (Lutterschmidt and Hutchison, 1997). Furthermore, although the mechanism(s) that causes LOE are presumed to involve impaired function of critical organs such as the heart and brain (Wang et al., 2014; Brijs et al., 2015; Jutfelt et al., 2019; Lefevre et al., 2021), they are not known and may differ among species and with warming rate (Currie and Schulte, 2014; Healy et al., 2018; Blasco et al., 2020). What is well-established, however, is that a given increase in acclimation (or acclimatization) temperature ( $\left.\mathrm{T}_{\mathrm{acc}}\right)$ is not linked to an equivalent increase in $\mathrm{CT}_{\max }$, both among and within fish species (Cossins and Bowler, 1987; Currie and Schulte, 2014; McKenzie et al., 2020). As a consequence, when comparing among species, tropical 
fishes have a lower thermal safety margin (TSM) than temperate, where TSM is calculated as the net difference between $\mathrm{T}_{\mathrm{acc}}$ and $\mathrm{CT}_{\max }$ (Comte and Olden, 2017a; b). Within a species, TSM also becomes smaller as a fish is acclimated to progressively warmer temperatures across its thermal range (e.g. McDonnell et al., 2019; McKenzie et al., 2020).

The notion that $\mathrm{CT}_{\max }$ could be used as a biomarker of sublethal toxic effects of contaminants dates from the 1970s (Cairns, 1971; Johnson, 1978; Dale Becker and Wolford, 1980) although the trait has only been used in this way on 11 species of subtropical or tropical fish (Table 2). As for all biomarkers that are complex physiological traits, $\mathrm{CT}_{\max }$ can provide a sensitive indicator of functional impairment caused by a contaminant. The lack of mechanistic understanding does, however, hinder comprehension of essential questions such as why $\mathrm{CT}_{\max }$ is modified by exposure to contaminants. Nonetheless, the $\mathrm{CT}_{\max }$ is interesting from a toxicological viewpoint because it is an incipient lethal threshold, therefore if it is reduced by contaminants this could have clear consequences for persistence of fish populations that suffer heat stress in polluted waters. The low TSM of subtropical and tropical species acclimated (or acclimatized) to warm waters may render them particularly vulnerable to heatwaves if they are in contaminated environments, especially if they are at temperatures close to the top of their thermal range.

There have been various investigations of effects on $\mathrm{CT}_{\max }$ of organic contaminants, notably pesticides, herbicides and common pollutants from industry such as phenol. Many of these molecules act as neurotoxins in vertebrates, hence they might be expected to influence $\mathrm{CT}_{\max }$ since LOE almost certainly has some neurological component (Lutterschmidt and Hutchison, 1997; Jutfelt et al., 2019). In many cases, the studies involved first establishing lethal concentrations (LC50) for the focal species, and then evaluating effects of sublethal concentrations on $\mathrm{CT}_{\max }$. Johnson (1978) studied the effects of four widely-used OP insecticides on $\mathrm{CT}_{\max }$ in the western mosquitofish Gambusia affinis, when acclimated to $20^{\circ} \mathrm{C}$ (Table 2). Gambusia affinis is a subtropical North American species that is highly eurythermal. As acetylcholinesterase inhibitors, OP insecticides have neurotoxic effects on fishes. Taking concentrations that were proposed as doses for field applications, the pesticides had no significant effects on mosquitofish $\mathrm{CT}_{\max }$ aside from chlorpyrifos, which caused a modest but significant decline in tolerance (Table 2). Takle et al. (1983) reported that sublethal concentrations of the biocide endothall, which is a protein phosphatase $A_{2}$ inhibitor, had no significant effect on $\mathrm{CT}_{\max }$ in another subtropical eurythermal north American species, the red shiner Cyprinella lutrensis, acclimated to $20^{\circ} \mathrm{C}$. In the same species, Messaad et al. (2000) investigated effects on $\mathrm{CT}_{\max }$ of 
sublethal concentrations of the triazine herbicide, atrazine, of an OP pesticide, terbufos, plus a cocktail of these, comparing effects on fish acclimated to $23^{\circ}$ or $30^{\circ} \mathrm{C}$. Toxic actions of atrazine in animals are supposedly related only to endocrine disruption. $\mathrm{CT}_{\max }$ of control fish increased with acclimation temperature but the contaminants caused more marked discrete declines in $\mathrm{CT}_{\max }$ at a $\mathrm{T}_{\text {acc }}$ of $30^{\circ} \mathrm{C}$ compared to $23^{\circ} \mathrm{C}$ (Table 2). In particular, the cocktail of the two pesticides caused a very profound decline in $\mathrm{CT}_{\max }$ at $30^{\circ} \mathrm{C}$ (Table 2). The mechanisms underlying the increased impact upon $\mathrm{CT}_{\max }$ at the higher temperatures may relate to increased metabolic rates and ventilatory water flows, which would cause increased uptake of contaminants from the water (Yang et al., 2000). Such results indicate that, as $T_{\text {acc }}$ increases, fishes may be more vulnerable to heat stress when they are also exposed to certain environmental contaminants (Messaad et al., 2000).

Patra et al. (2007) studied the effects on $\mathrm{CT}_{\max }$ of sublethal concentrations of three contaminants, endosulfan, an organochlorine pesticide; the OP chlorpyrifos, and an organic contaminant, phenol, in three subtropical Australian species, silver perch, eastern rainbowfish Melanotaenia duboulayi and western carp gudgeon Hypseleotris klunzingeri. Endosulfan is neurotoxic, a GABA-gated chloride channel antagonist, and a $\mathrm{Ca}^{2+}, \mathrm{Mg}^{2+}$ ATPase inhibitor. It is used to control insect pests but is acutely toxic to animals and is now banned in many countries. Phenol is one of the most common molecules in the chemical industry globally with a vast array of uses, it can have toxic effects on the central nervous system and heart of vertebrates. Although both endosulfan and chlorpyrifos caused significant declines in $\mathrm{CT}_{\max }$ in all species, while phenol was without effect. Kumar et al. (2016) reported that, in a euryhaline tropical Asian species the milkfish Chanos chanos acclimated to $28^{\circ} \mathrm{C}$, sublethal concentrations of endosulfan reduced $\mathrm{CT}_{\max }$ compared to a control (Table 2), an effect that was abolished by dietary supplements of vitamin $\mathrm{B}_{6}$, pyroxidine. Pyroxidine supplementation was linked to changes in tissue oxidative status and expression of the heat shock protein HSP70, which may have been related to the improved thermal tolerance (Kumar et al., 2016).

Zebral et al. (2018) investigated effects of the glyphosate-based herbicide,

367 Roundup $®$, on thermal tolerance of embryos of an endangered annual neotropical killifish, Austrolebias nigrofasciatus, hatched at $20^{\circ} \mathrm{C}$. This annual species leaves eggs in diapause in dried water courses during the dry season, which hatch when rains

370 arrive. Glyphosate is not considered to have acute toxic effects on vertebrates.

371 Glyphosate caused, however, a significant decline in $\mathrm{CT}_{\max }$ in hatched embryos held at

$37221^{\circ} \mathrm{C}$, when measured as cardiac arrest followed by mortality despite being

373 immediately returned to acclimation temperature (Table 2). Philippe et al. (2019) 
investigated the effects, on $\mathrm{CT}_{\max }$ of adults of the turquoise killifish Notobranchus furzeri, an annual species from Africa, of a highly persistent compound released from chlorinated aniline herbicides, 3,4-dichloroaniline (3,4-DCA). Fish were acclimated to either 24 or $28^{\circ} \mathrm{C}$ and exposed to two concentrations of 3,4-DCA, CT $\mathrm{max}_{\text {increased with }}$ $\mathrm{T}_{\mathrm{acc}}$ and the contaminant only caused a significant decline in $\mathrm{CT}_{\max }$ at the highest concentration at $28^{\circ} \mathrm{C}$ (Table 2).

There has been some investigation of effects of sublethal concentrations of toxic heavy metals on $\mathrm{CT}_{\max }$ in subtropical or tropical fish species. Cadmium and lead are both highly toxic to fishes, they attack various organs systems including gills, intestine and kidney. Notably, at sublethal concentrations they are neurotoxic (Green and Planchart, 2018) and, therefore, could influence thresholds for LOE and $C T_{\max }$. Carrier and Beitinger (1988) found that sublethal concentrations of cadmium decreased $\mathrm{CT}_{\max }$ in the red shiner acclimated to $20^{\circ} \mathrm{C}$, with a severity that increased with exposure dose and duration (Table 2). By contrast, Philippe et al. (2018) found that two sublethal concentrations of cadmium had no effect on $\mathrm{CT}_{\max }$ in the turquoise killifish acclimated to either 24 or $28{ }^{\circ} \mathrm{C}$, although $\mathrm{CT}_{\max }$ increased with acclimation temperature (Table 2). In the Mekong striped catfish Pangasianodon hypophthalmus acclimated to $34^{\circ} \mathrm{C}$, exposure to a sublethal concentration of lead caused a significant decline in $\mathrm{CT}_{\max }$, which was ameliorated by dietary supplementation with selenium or zinc (Kumar et al., 2017, 2018). This amelioration was concomitant with changes in redox balance of the tissues and in expression of HSPs, further circumstantial evidence that these elements of cell physiology may be involved in thermal tolerance in fishes.

There has also been some investigation of effects of nutrient contaminants on tolerance of warming. Nitrite is a pervasive form of nutrient pollution that enters aquatic habitats from diverse sources such as nitrogen-based fertilisers, livestock manure, sewage wastewater, and atmospheric deposits. The major toxic effect of nitrite is that it compromises blood oxygen transport in fishes, by causing methemoglobin formation (Lewis and Morris, 1986; Jensen, 2003). Watenpaugh et al. (1985) found that increasing sublethal concentrations of nitrite caused a progressive decline of $\mathrm{CT}_{\max }$ in the subtropical eurythermal channel catfish Ictalurus punctatus acclimated to $20^{\circ} \mathrm{C}$. The $\mathrm{CT}_{\max }$ was negatively correlated with blood methaemoglobin concentrations, which would seem to indicate that oxygen transport capacity is a determinant of $C T_{\max }$ in this species. Rodgers and De Boeck (2019) reported that a sub-lethal nitrite concentration caused a significant decline in $\mathrm{CT}_{\max }$ of in a globally extremely widespread subtropical eurytherm, the common carp Cyprinus carpio, when acclimated to $23^{\circ} \mathrm{C}$ (Table 2).

Within the extreme boundaries delineated by $\mathrm{CT}_{\max }$, thermal tolerance in fishes is typically evaluated with a thermal performance curve (TPC) that measures a trait of 
organismal performance over a range of temperatures to identify features such as a

412 thermal optimum for performance (Schulte et al., 2011; Currie and Schulte, 2014). The most common TPC is for aerobic metabolic scope (AS), the net capacity to supply oxygen for aerobic metabolic activities beyond basal maintenance (Fry, 1971; Schulte et al., 2011; Schulte, 2015). Very few studies have investigated how contaminants might influence elements of a TPC in subtropical or tropical fishes (Rodgers and De Boeck, 2019; Gomez Isaza et al., 2020a), also because this requires very extensive experimental work.

The study by Rodgers and De Boeck (2019) on common carp exposed to nitrite is a rare example where changes in $\mathrm{CT}_{\max }$ were related to aerobic performance and aerobic scope. Although nitrite reduced $\mathrm{CT}_{\max }$ this was not related to any decline in AS, indicating that $\mathrm{CT}_{\max }$ in the carp is not affected by capacity to provide oxygen for metabolism when warmed. The most comprehensive evaluations of how a contaminant might influence thermal tolerance and thermal sensitivity of performance in a tropical freshwater fish are studies on effects of nitrate on the silver perch (Gomez Isaza et al., 2020a, 2021b). Nitrate is the most abundant nutrient contaminant globally; although less toxic than nitrite it nonetheless shows persistently high concentrations in freshwaters due to agricultural runoff from nitrogen-based fertilisers, fossil fuel combustion and wastewater treatment plants. Nitrate also causes the formation of methaemoglobin, compromising blood oxygen carrying capacity (Gomez Isaza et al., 2020b). Gomez Isaza et al. (2020a) investigated whether nitrate exposure would increase susceptibility to elevated temperatures, measured as $\mathrm{CT}_{\max }$, and limit aerobic performance at warmer temperatures, measured as AS by swimming respirometry. In silver perch acclimated to $28{ }^{\circ} \mathrm{C}$, exposure to either 50 or $100 \mathrm{mg}^{-1}$ nitrate caused a decline in $\mathrm{CT}_{\max }$ that was not, however, observed in fish acclimated to a warmer temperature of $32^{\circ} \mathrm{C}$, despite these latter having higher overall $\mathrm{CT}_{\max }$ (Table 2). Furthermore, when swum at three temperatures $\left(28,32\right.$ or $\left.36^{\circ} \mathrm{C}\right)$, nitrate-exposed fish with a $\mathrm{T}_{\text {acc }}$ of $28^{\circ} \mathrm{C}$ showed a decline in AS (and swimming performance, see below) at $36{ }^{\circ} \mathrm{C}$, whereas those with a $\mathrm{T}_{\text {acc }}$ of $32{ }^{\circ} \mathrm{C}$ displayed a thermally-insensitive phenotype, with no change in AS or performance across temperatures. It was subsequently demonstrated that the silver perch with a $\mathrm{T}_{\text {acc }}$ of $32{ }^{\circ} \mathrm{C}$ exhibit thermally-related plastic compensation of the cardiorespiratory system, including increased gill surface area and greater ventricular thickness (Gomez Isaza et al., 2021b). This demonstrates how the thermal physiology of fishes may have complex interactions with their relative sensitivity to contaminants (Gomez Isaza et al., 2020a, 2021b). effects of contaminants on thermal tolerance in subtropical and tropical freshwater 
fishes is extremely limited, with a majority of information for subtropical species. Given that the mechanisms that cause LOE in $\mathrm{CT}_{\max }$ are not known, it is not possible to speculate about why some contaminants cause a decline in thermal tolerance while others do not. Some patterns can, however, be demonstrated in the limited dataset, as a basis for stimulating further research. When simply considering all $\mathrm{CT}_{\max }$ data in Table 2, there is a very clear and highly significant decline in TSM of control animals as $\mathrm{T}_{\text {acc }}$ increases (Fig 3). This analysis makes no effort to correct for warming rate, developmental stage (one species was studied as an embryo), but the results confirm that is known about effects of $T_{\text {acc }}$ on TSM in fishes (Comte and Olden, 2017a; b). The question that then arises is whether exposure to contaminants will exacerbate this effect, rendering tropical species even more vulnerable to warming events when they are in contaminated habitats. For those species in Table 2 where a contaminant caused a significant decline in $\mathrm{CT}_{\max }$, there was also a highly significant decline in TSM with $\mathrm{T}_{\text {acc }}$ (Figure 3). The intercept and slope of the relationships did not, however, differ significantly from those of control animals (Fig 3). Fig 4 shows, however, the proportional extent (as a percentage) to which contaminants reduced TSM compared to control conditions, as a function of $\mathrm{T}_{\text {acc. }}$. There was a significant effect whereby the higher $\mathrm{T}_{\text {acc }}$, the greater the extent to which a contaminant would compromise TSM (Fig 4). We show this figure precisely to highlight why it is unsatisfactory, namely that there is a critical lack of information for effects of contaminants on TSMs of fishes at warm tropical temperatures. There are major reasons for caution in interpreting this figure. Firstly, the four points at $30^{\circ} \mathrm{C}$ and above are from two species, red shiner and striped catfish; the three points at $30^{\circ} \mathrm{C}$ all come the from the study on red shiner that demonstrated how two pesticides and their cocktail caused much more profound declines in $\mathrm{CT}_{\max }$ in fish acclimated to $30^{\circ}$ compared to $23^{\circ} \mathrm{C}$ by (Messaad et al. 2000). Indeed, at $30{ }^{\circ} \mathrm{C}$ the pesticide cocktail reduced the TSM by over $80 \%$ compared to uncontaminated animals (Fig 4). Secondly, as mentioned above, warmer temperatures did not increase susceptibility to nitrate in silver perch, because of plastic physiological responses by this eurythermal subtropical species (Gomez Isaza et al., $2020 a, 2021 b$ ), so this data is not carried on the figure. Therefore, it is very important to extend the knowledge base on how contaminants affect thermal tolerance of tropical species, to investigate whether they are particularly vulnerable to impacts of heatwaves when exposed to common pollutants. This is highly relevant to the life cycle of many tropical species that, during dry seasons, may find themselves confined to increasingly smaller water bodies, which will tend to concentrate any pollutants as water evaporates and also to be submitted to extremes of warmth due to solar radiation (Patra et al., 2007, 2015). 


\section{Critical swimming speed as a biomarker}

Swimming performance has clear ecological relevance for many fish species, so measures of performance can provide valuable biomarkers of toxic effects of aquatic contaminants (Cairns, 1966; Beamish, 1978; Tudorache et al., 2008; McKenzie et al. 2007, 2008; Domenici, 2010). In particular, the critical swimming speed protocol ( $U_{\text {crit, }}$ Brett, 1964) was first proposed as a sublethal physiological biomarker more than 50 years ago (Cairns, 1966; Beamish, 1978). The $U_{\text {crit }}$ protocol allows investigation of proximate mechanisms that underly impaired performance following exposure to contaminants, so gaining insight into mechanisms of toxic effects in target organs such as skeletal muscle (Beaumont et al., 1995, 2000; Tierney et al., 2007) or the heart (Khursigara et al., 2019).

The $U_{\text {crit }}$ protocol exposes fish to stepwise increases in speed in a swimming respirometer, to establish the speed at which it fatigues. The knowledge base is dominated by work on temperate species and especially salmonids, while the Deepwater Horizon disaster led to extensive research on subtropical marine species. Studies have demonstrated impacts of many classes of contaminant under controlled laboratory conditions, including metals (e.g. Beaumont et al., 1995), xenobiotic organics (Wood et al., 1996; Tierney et al., 2007), crude oil itself (Stieglitz et al., 2016), waste products such as ammonia (Shingles et al., 2001), and other consequences of anthropogenic pressures, such as harmful algae (Corriere et al., 2020). Critical swimming speed has also been used to show impacts of exposure to water containing complex contaminant mixtures (e.g. Goertzen et al., 2012; Folkerts et al., 2020) including by exposing fishes in cages (McKenzie et al., 2007). The zebrafish is an important model vertebrate species for laboratory studies to demonstrate impacts of contaminants on swimming performance, to demonstrate toxic effects and their mechanisms (e.g. Thomas and Janz, 2011; Gerger et al., 2015; Lucas et al., 2016;

512 Folkerts et al., 2017). Such studies on zebrafish have never, however, been related to conditions in their natural environment in tropical south Asia, so we will not review them here.

There are so few studies that, to our knowledge, have used $U_{\text {crit }}$ as a biomarker of effects of contaminants on subtropical and tropical freshwater species (other than zebrafish), that it is almost trivial to review them. We do this, however, to stimulate

518 further work. One necessity for such studies is, of course, access to a swim tunnels or 519 swim flume. These are now commercially available, which opens up possibilities of 520 using swimming performance as a valuable biomarker to support decision-making for water quality control in tropical countries. This is especially relevant for the protection of 
economically valuable species that perform remarkable migrations through tropical river systems that are at increasing risk of contamination by multiple pollutants (Hogan et al., 2007; Duponchelle et al., 2016; Speranza et al., 2016). Other traits of performance such as the escape response (Tudorache et al., 2008; McKenzie et al., 2009) or aspects of swimming behavior (Little and Finger, 1990), which do not require a swim tunnel, can also be used as biomarkers.

Two studies have investigated effects of organic pollutants on $U_{\text {crit }}$ in freshwater subtropical/tropical species. Perfluorooctane sulfonic acid (PFOS) is a fluorosurfactant with a wide range of commercial and industrial applications, which has become a pervasive and persistent pollutant of freshwaters globally (Augustsson et al., 2021). Xia et al. (2015) studied effects of a range of sublethal concentrations of PFOS on $U_{\text {crit }}$ in qingbo Spinibarbus sinensis, a subtropical Asian species acclimated to two temperatures, $18^{\circ}$ and $28^{\circ} \mathrm{C}$. Increasing concentrations of PFOS caused progressive declines in $U_{\text {crit, }}$ while $T_{\text {acc }}$ had no interaction with these impairments. Swimming respirometry showed that the decline in performance was linked to reduced swimming efficiency, in that higher rates of oxygen uptake were needed to achieve a given a swimming speed. The author suggested that this might be due to sensorimotor or muscle tissue impairments, due to toxic effects of PFOS. McKenzie et al. (2017) used $U_{\text {crit }}$ to evaluate individual variation in sub-lethal sensitivity to the OP pesticide trichlorfon in a globally widespread tropical species, the Nile tilapia. At a $\mathrm{T}_{\text {acc }}$ of $27^{\circ} \mathrm{C}$, trichlorfon reduced $U_{\text {crit }}$ significantly and fish only exhibited a partial recovery $96 \mathrm{~h}$ after return to control freshwater. The decline in $U_{\text {crit }}$ was due to reduced swimming efficiency, which was attributed to the fact that OPs are acetylcholinesterase inhibitors that interfere with cholinergic nerve function at motor endplates and in the central nervous system of vertebrates. This would impair neuromuscular coordination in fishes, reducing their swimming efficiency (Tierney et al., 2007; McKenzie et al., 2017). This study is a rare investigation of how individuals in populations differ in their sensitivity to a pollutant, finding that intrinsically efficient swimmers were the least affected by the OP (McKenzie et al., 2017).

Gomez Isaza et al. (2020a) investigated effects of nitrate, the most prevalent nutrient contaminant globally, on thermal sensivity of swimming performance in silver perch, acclimated to either 28 or $32{ }^{\circ} \mathrm{C}$. Two sublethal exposure concentrations were evaluated at three temperatures $\left(28,32\right.$ and $\left.36^{\circ} \mathrm{C}\right)$, to reveal complex effects whereby fish acclimated to $28{ }^{\circ} \mathrm{C}$ had better overall $U_{\text {crit }}$ performance than those acclimated to $32{ }^{\circ} \mathrm{C}$. Exposure to nitrate, however, impaired $\mathrm{U}_{\text {crit }}$ of the $28^{\circ} \mathrm{C}$ fish, in a manner proportional to nutrient concentration, but was without effect on performance of the 32 ${ }^{\circ} \mathrm{C}$ fish. This absence of effects of nitrate in fish acclimated to $32{ }^{\circ} \mathrm{C}$ was unexpected 
but paralleled the findings for $\mathrm{CT}_{\max }$ and aerobic performance that are reported above. In a study on the subtropical highly eurythermal spangled perch Leiopotherapon unicolor, Gomez Isaza et al. (2020b) investigated effects on $U_{\text {crit }}$ of combinations of sublethal nitrate and low $\mathrm{pH}$ (acidification). The $U_{\text {crit }}$ was impaired by both nitrate and acid $\mathrm{pH}$, with most severe impairment being in fish at the highest nitrate concentration and low $\mathrm{pH}$, although the combined effect was additive rather than synergistic. These impairments in performance were linked to a reduced capacity to raise oxygen uptake during swimming, leading to lower AAS. These proximate effects could, in turn, be attributed to measured negative effects of nitrate and low $\mathrm{pH}$ on blood oxygen carrying capacity (Gomez Isaza et al., 2020b). Such multifactorial studies provide excellent but challenging templates for future investigations of effects of contaminants on the environmental tolerance and physiological performance of freshwater tropical fishes.

\section{Conclusions}

This review demonstrates that $\mathrm{O}_{2 \text { crit, }}, \mathrm{CT}_{\max }$ and $\mathrm{U}_{\text {crit }}$ can all be useful physiological biomarkers of the toxicological effects of water contaminants on tropical and subtropical freshwater fishes. Understanding the interactive effects on fish physiology of sublethal exposures to contaminants, hypoxia and heatwaves will be crucial for monitoring the health of populations and projecting their biological consequences before serious changes in population size occur. This review very clearly demonstrates the need to extend the knowledge base to more species and contaminants, to better evaluate subtropical and tropical freshwater fish vulnerability in light of ongoing climate change. Complex physiological traits should be used to support decision-making in formulating water quality criteria for fishes and conservation strategies for their habitats, to protect their rich biodiversity. They may be particularly useful in procedures to identify adverse outcome pathways (van der Oost et al., 2020). Despite the technical challenges involved, future studies should consider interactions among pollutants, hypoxia and warming in tropical fishes, as the stresses all co-occur in nature.

\section{Acknowledgments}

The studies performed by the authors were funded by grants from the Coordination for the Improvement of Higher Education Personnel (CAPES) and the National Council for Scientific and Technological Development (CNPq) of Brazil, and by the São Paulo Research Foundation (FAPESP).

\section{Conflict of Interest}




\section{Data Availability Statement}

599 The data that support the findings of this study are available from the 600 corresponding author upon reasonable request.

601 


\section{References}

Almeida-Val, V.M.F., Gomes, A.R.C., Lopes, N.P. (2006). Metabolic and physiological adjustments to low oxygen and high temperature in fishes of the Amazon. In A.L. Val, V.M.F. Almeida-Val, \& D.J. Randall (Eds.), Fish Physiology (pp. 443-359). Elsevier, Heidelberg.

Anelli Jr., L.C. (2010). Efeitos de diferentes formulações comerciais do herbicida Roundup $®$ sobre a função cardiorespiratória de matrinxã, Brycon amazonicus (Teleostei, Characidae). [Doctoral dissertation, Federal University of São Carlos].

Antonijevic, B., Stojiljkovic, M.P. (2007). Unequal efficacy of pyridinium oximes in acute organophosphate poisoning. Clinical Medicine \& Research, 5, 71-82.

Augustsson, A., Lennqvist, T., Osbeck, C.M.G., Tibblin, P., Glynn, A., Nguyen, M.A., Westberg, E., Vestergren, R. (2021). Consumption of freshwater fish: A variable but significant risk factor for PFOS exposure. Environmental Research, 192, 110284.

Barreto, L.S., Souza, A.T.D.C., Martins, C.C., Araujo, S.B.L., Oliveira Ribeiro, C.A. (2020). Urban effluents affect the early development stages of Brazilian fish species with implications for their population dynamics. Ecotoxicology and Environmental Safety, 188, 109907.

Beamish, F.W.H. (1978). Swimming capacity. In: Hoar, W.S. \& Randall, D.J. (Eds.), Fish Physiology (pp 101-187). New York: Academic Press.

Beaumont, M., Butler, P., Taylor, E. (1995). Plasma ammonia concentration in brown trout in soft acidic water and its relationship to decreased swimming performance. Journal of Experimental Biology, 198, 2213-20.

Beaumont, M.W., Taylor, E.W., Butler, P.J. (2000). The resting membrane potential of white muscle from brown trout (Salmo trutta) exposed to copper in soft, acidic water. Journal of Experimental Biology, 203, 2229-2236.

Beitinger, T. \& Lutterschmidt, W. (2011). Temperature measures of thermal tolerance. In: A.P. Farrell (Ed.), Encyclopedia of fish physiology: from genome to environment (pp. 1695-1702). Elsevier Ltd.

Beltrão, H., Zuanon, J., Ferreira, E. (2019). Checklist of the ichthyofauna of the Rio Negro basin in Brazilian Amazon. ZooKeys, 881, 53-89.

Bergsson, H., Andersen, N.R., Svendsen, M.B.S, Hansen, P.J., Steffensen, J.F. (2019). Respiratory physiology of european plaice (Pleuronectes platessa) exposed to Prymnesium parvum. Fishes, 4, 32. 
Bilberg, K., Malte, H., Wang, T., Baatrup, E. (2010). Silver nanoparticles and silver nitrate cause respiratory stress in Eurasian perch (Perca fluviatilis). Aquatic Toxicology, 96, 159-165.

Blasco, F.R., Esbaugh, A.J., Killen, S.S., Rantin, F.T., Taylor, E.W., McKenzie, D.J. (2020). Using aerobic exercise to evaluate sub-lethal tolerance of acute warming in fishes. Journal of Experimental Biology, 223, jeb218602.

Braz-Mota, S., Sadauskas-Henrique, H., Duarte, R.M., Val, A.L., Almeida-Val, V.M.F. (2015). Roundup $®$ exposure promotes gills and liver impairments, DNA damage and inhibition of brain cholinergic activity in the Amazon teleost fish Colossoma macropomum. Chemosphere, 135, 53-60.

Brett, JR. (1958). Implications and assessments of environmental stress. In: P.A. Larkin (Ed.), The investigation of fish-power problems (pp. 69-93). Vancouver, BC: University of British Columbia.

Brett, JR. (1964). The respiratory metabolism and swimming performance of young sockeye salmon. Journal of the Fisheries Research Board of Canada, 21, 11831226.

Brijs, J., Jutfelt, F., Clark, T.D., Gräns, A., Ekström, A., Sandblom, E. (2015). Experimental manipulations of tissue oxygen supply do not affect warming tolerance of European perch. Journal of Experimental Biology, 218, 2448-2454.

Cairns, J. (1966). Don't be half-safe- the current revolution in bio-assay techniques. Proc. 21 St Ind. Waste Conf. Purdue Univ. Engng Extn Ser. No. 121.

Cairns. Jr.J. (1971). Thermal pollution: A cause for concern on. Water Pollution Control Federation, 43:55-66.

Calow, P. \& Forbes, V.E. (1998). How do physiological responses to stress translate into ecological and evolutionary processes? Comparative Biochemistry and Physiology Part A: Molecular \& Integrative Physiology, 120, 11-16.

Carrier, R., Beitinger, T.L. (1988). Reduction in thermal tolerance of Notropis lutrensis and Pimephales promelas exposed to cadmium. Water Research, 22, 511-515.

Cazenave, J., Bacchetta, C., Parma, M.J., Scarabotti, P.A., Wunderlin, D.A. (2009). Multiple biomarkers responses in Prochilodus lineatus allowed assessing changes in the water quality of Salado River basin (Santa Fe, Argentina). Environmental Pollution, 157, 3025-3033.

Claireaux, G., Chabot, D. (2016). Responses by fishes to environmental hypoxia: integration through Fry's concept of aerobic metabolic scope. Journal of Fish Biology, 88, 232-51.

Comte, L., Olden, J.D. (2017a). Climatic vulnerability of the world's freshwater and marine fishes. Nature Climate Change, 7, 718-722. 
Comte, L., Olden, J.D. (2017b). Evolutionary and environmental determinants of freshwater fish thermal tolerance and plasticity. Global Change Biology, 23, 728736.

Corriere, M., Baptista, M., Paula, J.R., Repolho, T., Rosa, R,, Costa, P.R., Soliño, L. (2020). Impaired fish swimming performance following dietary exposure to the marine phycotoxin okadaic acid. Toxicon, 179, 53-59.

Cossins, A.R. \& Bowler, K. (1987). Temperature Biology of Animals. London: Chapman and Hall.

Costa, M.F. \& Barletta, M. (2016). Special challenges in the conservation of fishes and aquatic environments of South America. Journal of Fish Biology, 89, 4-11.

Costa, M.J., Ribeiro, L.R., Salla, R.F., Gamero, F.U., Alves, L.M.L.M., Silva-Zacarin, E.C.M. (2015). Effects of the organophosphorus pesticide Folisuper 600 (methyl parathion) on the heart function of bullfrog tadpoles, Lithobates catesbeianus (Shaw, 1802). Brazilian Journal of Biology, 75, 163-168.

Currie, S. \& Schulte, P.M. (2014). Thermal stress. In: D.H. Evans, J. Claiborne, S. Currie (Eds.), The physiology of fishes (pp. 257-279).Boca Raton: CRC Press.

Daam, M.A. \& Van Den Brink, P.J. (2010). Implications of differences between temperate and tropical freshwater ecosystems for the ecological risk assessment of pesticides. Ecotoxicology, 19, 24-37.

Dalzochio, T., Rodrigues, G.Z.P., Petry, I.E., Gehlen, G., da Silva, L.B. (2016). The use of biomarkers to assess the health of aquatic ecosystems in Brazil: a review. International Aquatic Research, 8, 283-298.

Dale Becker, C. \& Wolford, M.G. (1980). Thermal resistance of juvenile salmonids sublethally exposed to nickel, determined by the critical thermal maximum method. Environmental Pollution Series A, Ecological and Biological, 21, 181189.

de Andrade Waldemarin, K.C., Alves, R.N., Beletti, M.E., Rantin, F.T., Kalinin, A.L. (2012). Copper sulfate affects Nile tilapia (Oreochromis niloticus) cardiomyocytes structure and contractile function. Ecotoxicology, 21, 783-794.

De Angelis, C.F. (2017). Efeitos do surfactante nonilfenol etoxilado em peixes: função cardiorrespiratória e histopatologia em Tilápia-do-Nilo, Oreochromis niloticus, em condições de normóxia e hipóxia aquáticas. [Master's dissertation, Federal University of São Carlos]. UA Campus Repository. https://repositorio.ufscar.br/handle/ufscar/9542

Di Giulio, R.T. \& Clark, B.W. (2015). The Elizabeth River story: A case study in evolutionary toxicology. Journal of Toxicology and Environmental Health Part B, 18, 259-298. 
Diaz, R.J. \& Breitburg, D.L. (2009). Hypoxia. In: J.G. Richards, A.P. Farrell, C.J. Brauner (Eds), Hypoxia, Fish Physiology (vol. 27, pp. 1-23). Physiology. Elsevier. Domenici, P. (2010). Context-dependent variability in the components of fish escape response: integrating locomotor performance and behavior. Journal Experimental Zoology Part A: Ecological and Integrative Physiology, 313, 59-79.

Domenici, P. \& Hale, M.E. (2019). Escape responses of fish: a review of the diversity in motor control, kinematics and behaviour. Journal of Experimental Biology, 222, jeb166009.

Driedzic, W.R. \& Gesser, H. (1994). Energy metabolism and contractility in ectothermic vertebrate hearts: hypoxia, acidosis, and low temperature. Physiological Reviews, 74, 221-258.

Duponchelle, F., Pouilly, M., Pécheyran, C., Hauser, M., Renno, J.F., Panfili, J., Darnaude, A.M., García-Vasquez, A., Carvajal-Vallejos, F., García-Dávila, C,, Doria, C., Bérail, S., Donard, A., Sondag, F., Santos, R.V., Nuñez, J., Point, D., Labonne, M., Baras, E. (2016). Trans-Amazonian natal homing in giant catfish. Journal of Applied Ecology, 53, 1511-1520.

Farrell, A.P. (2007). Tribute to P.L. Lutz: a message from the heart--why hypoxic bradycardia in fishes? Journal of Experimental Biology, 210, 1715-1725.

Folkerts, E.J., Blewett, T.A., He, Y., Goss, G.G. (2017). Alterations to juvenile zebrafish (Danio rerio) swim performance after acute embryonic exposure to sub-lethal exposures of hydraulic fracturing flowback and produced water. Aquatic Toxicology, 193, 50-59.

Folkerts, E.J., Heuer, R.M., Flynn, S., Stieglitz, J.D., Benetti, D.D., Alessi, D.S., Goss, G.G., Grosell, M. (2020). Exposure to hydraulic fracturing flowback water impairs mahi-mahi (Coryphaena hippurus) cardiomyocyte contractile function and swimming performance. Environmental Science \& Technology, 54, 13579-13589.

Fry, F.E.J. (1971). The effect of environmental factors on the physiology of fish. In: W.S. Hoar \& D.J. Randall (Eds.), Fish physiology (vol 6, pp. 1-98). New York: Academic Press.

Gamperl, A.K., Driedzic, W.R. (2009). Cardiovascular function and cardiac metabolism. In J.G. Richards, A.P. Farrell \& C.J. Brauner (Eds.), Fish Physiology (vol. 27, pp. 301-360). Academic Press.

Gerger, C.J., Thomas, J.K., Janz, D.M., Weber, L.P., Gerger, C.J., Thomas, J.K., Janz, A.D.M., Weber, A.L.P. (2015). Acute effects of b-naphthoflavone on cardiorespiratory function and metabolism in adult zebrafish (Danio rerio). Fish Physiology Biochemistry, 41, 289-298. 
Goertzen, M.M., Hauck, D.W., Phibbs, J., Weber, L.P., Janz, D.M. (2012). Swim performance and energy homeostasis in spottail shiner (Notropis hudsonius) collected downstream of a uranium mill. Ecotoxicology and Environmental Safety, 75, 142-150.

Gomez Isaza, D.F., Cramp, R.L., Franklin, C.E. (2020a). Thermal acclimation offsets the negative effects of nitrate on aerobic scope and performance. Journal of Experimental Biology, 223, jeb224444.

Gomez Isaza, D.F., Cramp, R.L., Franklin, C.E. (2020b). Simultaneous exposure to nitrate and low $\mathrm{pH}$ reduces the blood oxygen-carrying capacity and functional performance of a freshwater fish. Conservation Physiology, 8, 1-15.

Gomez Isaza, D.F., Cramp, R.L., Franklin, C.E. (2021a). Exposure to nitrate increases susceptibility to hypoxia in fish. Physiological and Biochemical Zoology, 94, 124142.

Gomez Isaza, D.F., Cramp, R.L., Franklin, C.E. (2021b). Thermal plasticity of the cardiorespiratory system provides cross-tolerance protection to fish exposed to elevated nitrate. Comparative Biochemistry and Physiology Part C: Toxicology \& Pharmacology, 240, 108920

Green, A.J. \& Planchart, A. (2018). The neurological toxicity of heavy metals: A fish perspective. Comparative Biochemistry and Physiology Part C: Toxicology \& Pharmacology, 208, 12-19.

Gupta, U., \& Guha, S. (2006). Microcystin toxicity in a freshwater fish, Heteropneustes fossilis (Bloch). Current Science, 91, 1261-1271.

Habary, A., Johansen, J.L., Nay, T.J., Steffensen, J.F., Rummer, J.L. (2017). Adapt, move or die - how will tropical coral reef fishes cope with ocean warming? Global Change Biology, 23, 566-577.

Healy, T.M, Brennan, R.S., Whitehead, A., Schulte, P.M. (2018). Tolerance traits related to climate change resilience are independent and polygenic. Global Change Biology, 24, 5348-5360.

Higgins, J., Zablocki, J., Newsock, A., Krolopp, A., Tabas, P., Salama, M. (2021). Durable freshwater protection: A framework for establishing and maintaining long-term protection for freshwater ecosystems and the values they sustain. Sustainability, 13, 1-17.

Hogan, Z., Baird, I.G., Radtke, R., Vander Zanden, M.J. (2007). Long distance migration and marine habitation in the tropical Asian catfish, Pangasius krempfi. Journal of Fish Biology, 71, 818-832.

Holt, M.S. (2000). Sources of chemical contaminants and routes into the freshwater environment. Food and Chemical Toxicology, 38, S21-S27. 
Hook, S.E., Gallagher, E.P., Batley, G.E. (2014). The role of biomarkers in the assessment of aquatic ecosystem health. Integrated Environmental Assessment and Management, 10, 327-341.

Incardona, J.P., Collier, T.K., Scholz, N.L. (2004). Defects in cardiac function precede morphological abnormalities in fish embryos exposed to polycyclic aromatic hydrocarbons. Toxicology and Applied Pharmacology, 196, 191-205.

Incardona, J.P. \& Scholz, N.L. (2017). Environmental pollution and the fish heart In A.K. Gamperl, T.E. Gillis, A.P. Farrell \& C.J. Brauner (Eds.), Fish Physiology (vol. 36, pp. 373-433), Academic Press.

Isaza, D.G. (2020). Anthropogenic disturbances to freshwater taxa: Interactions between nitrate and additional stressors on various physiological traits. [PhD Thesis, School of Biological Sciences, The University of Queensland]. https://doi.org/10.14264/ea9709d.

Islam, S.M.M., Rahman, M.A., Nahar, S., Uddin, M.H., Haque, M.M., Shahjahan, M. (2019). Acute toxicity of an organophosphate insecticide sumithion to striped catfish Pangasianodon hypophthalmus. Toxicology Reports, 6, 957-962.

Jensen, F.B. (2003). Nitrite disrupts multiple physiological functions in aquatic animals. Comparative Biochemistry and Physiology - A Molecular and Integrative Physiology, 135, 9-24.

Jobling, S. \& Tyler, C.R. (2003). Endocrine disruption in wild freshwater fish. Pure and Applied Chemistry, 75, 2219-2234.

Johnson, C.R. (1978). The effects of sublethal concentrations of five organophosphorus insecticides on temperature tolerance, reflexes, and orientation in Gambusia affinis affinis (Pisces: Poeciliidae). Zoological Journal of the Linnean Society, 64, 63-70.

Joyce, W., Simonsen, M., Gesser, H., Wang, T. (2016). The effects of hypoxic bradycardia and extracellular $\mathrm{HCO} 3-/ \mathrm{CO} 2$ on hypoxic performance in the eel heart. Journal of Experimental Biology, 219, 302-305.

Jutfelt, F., Roche, D.G., Clark, T.D., Norin, T., Binning, S.A., Speers-Roesch, B., Amcoff, M., Morgan, R., Andreassen, A.H., Sundin, J. (2019). Brain cooling marginally increases acute upper thermal tolerance in Atlantic cod. Journal of Experimental Biology, 222, jeb208249.

Khursigara, A.J., Ackerly, K.L., Esbaugh, A.J. (2019). Oil toxicity and implications for environmental tolerance in fish. Comparative Biochemistry and Physiology Part C: Toxicology \& Pharmacology, 220, 52-61.

Kroon, F., Streten, C., Harries, S. (2017). A protocol for identifying suitable biomarkers to assess fish health: A systematic review. PLoS One, 12, e0174762. 
Kumar, N., Ambasankar, K., Krishnani, K.K., Kumar, P., Akhtar, M.S., Bhushan, S., Minhas, P.S. (2016). Dietary pyridoxine potentiates thermal tolerance, heat shock protein and protect against cellular stress of Milkfish (Chanos chanos) under endosulfan-induced stress. Fish \& Shellfish Immunology, 55, 407-414.

Kumar, N., Krishnani, K.K., Chandan, N.K., Singh, N.P. (2018). Dietary zinc potentiates thermal tolerance and cellular stress protection of Pangasius hypophthalmus reared under lead and thermal stress. Aquaculture Research, 49, 1105-1115.

Kumar, N., Krishnani, K.K., Gupta, S.K, Singh, N.P. (2017). Selenium nanoparticles enhanced thermal tolerance and maintain cellular stress protection of Pangasius hypophthalmus reared under lead and high temperature. Respiratory Physiology \& Neurobiology, 246, 107-116.

Lacher, T.E. \& Goldstein, M.I. (1997). Tropical ecotoxicology: Status and needs. Environmental Toxicology and Chemistry, 16, 100-111.

Langiano, V. do C., Martinez, C.B. (2008). Toxicity and effects of a glyphosate-based herbicide on the Neotropical fish Prochilodus lineatus. Comparative Biochemistry and Physiology Part C: Toxicology \& Pharmacology, 147, 22-231.

Lefevre, S., Wang, T., McKenzie, D.J. (2021). The role of mechanistic physiology in investigating impacts of global warming on fishes. Journal of Experimental Biology, 224, jeb238840.

Lewis, W.M. \& Morris, D.P. (1986). Toxicity of nitrite to fish: A Review. Transactions of the American Fisheries Society, 115, 183-195.

Little, E.E., Finger, S.E. (1990). Swimming behavior as an indicator of sublethal toxicity in fish. Environ Toxicol Chem 9,13-19.

Lucas, J., Percelay, I., Larcher, T., Lefrançois, C. (2016). Effects of pyrolytic and petrogenic polycyclic aromatic hydrocarbons on swimming and metabolic performance of zebrafish contaminated by ingestion. Ecotoxicology and Environmental Safety, 132,145-152.

Lutterschmidt, W.I., Hutchison, V.H. (1997). The critical thermal maximum: history and critique. Canadian Journal of Zoology, 75, 1561-1574.

Mandic, M., Todgham, A.E., Richards, J.G. (2009) Mechanisms and evolution of hypoxia tolerance in fish. Proceedings. Biological Sciences $B, \mathbf{2 7 6}, 735-744$.

Martins, N.D., Colvara, W., Rantin, F.T., Kalinin, A.L. (2011). Microcystin-LR: How it affects the cardio-respiratory responses to hypoxia in Nile tilapia, Oreochromis niloticus. Chemosphere, 84, 154-159.

Martins, N.D., Yunes, J.S., McKenzie, D.J. Rantin, F.T., Kalinin, A.L., Monteiro, D.A. (2019). Microcystin-LR exposure causes cardiorespiratory impairments and 
tissue oxidative dama ge in trahira, Hoplias malabarius. Ecotoxicology and Environmental Safety, 173, 436-443.

Martins, N.F. (2018). Efeitos do contaminante emergente triclosan sobre a função cardiorespiratória do matrinxã, Brycon amazonicus, em normóxia e durante hipóxia gradual. [Doctoral dissertation, Federal University of São Carlos]. UA Campus Repository. https://repositorio.ufscar.br/handle/ufscar/10718

Martins, N.D., Yunes, J.S., Monteiro, D.A., Rantin, F.T., Kalinin, A.L. (2017). Microcystin-LR leads to oxidative damage and alterations in antioxidant defense system in liver and gills of Brycon amazonicus (SPIX \& AGASSIZ, 1829). Toxicon, 139, 109-116.

Mason, C.F. (2002). Biology of freshwater pollution. London: Pearson Education. Matson, C.W., Timme-Laragy, A.R., Di Giulio, R.T. (2008). Fluoranthene, but not benzo[a]pyrene, interacts with hypoxia resulting in pericardial effusion and lordosis in developing zebrafish. Chemosphere, 74, 149-154.

Menéndez-Helman, R.J., Ferreyroa, G.V., dos Santos Afonso, M., Salibián, A. (2012). Glyphosate as an acetylcholinesterase inhibitor in Cnesterodon decemmaculatus. Bulletin of Environmental Contamination and Toxicology, 88, 6-9.

McArley, T.J., Hickey, A.J.R., Herbert, N.A. (2018). Hyperoxia increases maximum oxygen consumption and aerobic scope of intertidal fish facing acutely high temperatures. Journal Experimental Biology, 221, jeb189993

McDonnell, L.H., Reemeyer, J.E., Chapman, L.J. (2019). Independent and interactive effects of long-term exposure to hypoxia and elevated water temperature on behavior and thermal tolerance of an equatorial cichlid. Physiological and Biochemical Zoology, 92, 253-265.

McKenzie, D.J., Blasco, F.R., Belão, T.C., Killen, S.S., Martins, N.D., Taylor, E.W., Rantin, F.T. (2017). Physiological determinants of individual variation in sensitivity to an organophosphate pesticide in Nile tilapia Oreochromis niloticus. Aquatic Toxicology, 189, 108-114.

McKenzie, D.J., Garofalo, E., Winter, M.J., Ceradini, S., Verweij, F., Day, N., Hayes, R., van der Oost, R., Butler, P.J., Chipman, J.K., Taylor, E.W. (2007). Complex physiological traits as biomarkers of the sub-lethal toxicological effects of pollutant exposure in fishes. Philosophical Transactions of the Royal Society B, 362, 2043-2059.

McKenzie, D.J., Shingles, A., Claireaux, G., Domenici, P. (2009). Sublethal Concentrations of Ammonia Impair Performance of the Teleost Fast-Start Escape Response. Physiol Biochem Zool 82, 353-362. 
McKenzie, D.J., Zhang, Y., Eliason, E.J., Schulte, P.M., Blasco, F.R., Claireaux, G., Nati, J.J.H., Farrell, A.P. (2020). Intraspecific variation in tolerance of of warming in fishes. Journal of Fish Biology, 1-20. https://doi.org/10.1111/jfb.14620

McRae, N.K., Gaw, S., Glover, C.N. (2018). Effects of waterborne cadmium on metabolic rate, oxidative stress, and ion regulation in the freshwater fish, inanga (Galaxias maculatus). Aquatic Toxicology, 194, 1-9.

Messaad, I.A., Peters, E.J., Young, L. (2000). Thermal tolerance of red shiner (Cyprinella lutrensis) after exposure to atrazine, terbufos, and their mixtures. Bulletin of Environmental Contamination and Toxicology, 64, 748-754.

Modesto, K.A. \& Martinez, C.B. (2010). Effects of Roundup Transorb on fish: hematology, antioxidant defenses and acetylcholinesterase activity. Chemosphere, 81, 781-787.

Monteiro, D.A., Taylor, E.W., McKenzie, D.J., Rantin, F.T., Kalinin, A.L. (2020). Interactive effects of mercury exposure and hypoxia on ECG patterns in two Neotropical freshwater fish species: matrinxã, Brycon amazonicus and traíra, Hoplias malabaricus. Ecotoxicology, 29, 375-388.

Monteiro, D.A., Taylor, E.W., Rantin, F.T., Kalinin, A.L. (2017). Impact of waterborne and trophic mercury exposures on cardiac function of two ecologically distinct Neotropical freshwater fish Brycon amazonicus and Hoplias malabaricus. Comparative Biochemistry and Physiology Part C: Toxicology \& Pharmacology, 201, 26-34.

Monteiro, D.A., Thomaz, J.M., Rantin, F.T., Kalinin, A.L. (2013). Cardiorespiratory responses to graded hypoxia in the neotropical fish matrinxã (Brycon amazonicus) and traíra (Hoplias malabaricus) after waterborne or trophic exposure to inorganic mercury. Aquatic Toxicology, 140(41), 346-355.

Mu, J., Chernick, M., Dong, W., Di Giulio, R. T., \& Hinton, D. E. (2017). Early life coexposures to a real-world PAH mixture and hypoxia result in later life and next generation consequences in medaka (Oryzias latipes). Aquatic Toxicology, 190, 162-173.

Noyes, P.D., Lema, S.C. (2015). Forecasting the impacts of chemical pollution and climate change interactions on the health of wildlife. Current Zoology, 61, 669689.

Noyes, P.D., McElwee, M.K., Miller, H.D., Clark, B.W., Van Tiem, L.A., Walcott, K.C., Erwin, K.N., Levin, E.D. (2009). The toxicology of climate change: Environmental contaminants in a warming world. Environment International, 35, 971-986.

Olle, C.D. (2007). Efeito do inseticida organofosforado metilparation (Folisuper 600BR) sobre a função cardio-respiratória do peixe teleósteo matrinxã, Brycon cephalus. 
[Doctoral dissertation, Federal University of São Carlos]. UA Campus Repository. https://repositorio.ufscar.br/handle/ufscar/1207

Patra RW, Chapman JC, Lim RP, Gehrke PC, Sunderam RM. 2015. Interactions between water temperature and contaminant toxicity to freshwater fish. Environmental Toxicology and Chemistry, 34, 1809-1817.

Patra, R.W., Chapman, J.C., Lim, R.P., Gehrke, P.C. (2007). The effects of three organic chemicals on the upper thermal tolerances of four freshwater fishes. Environmental Toxicology and Chemistry, 26, 1454-1459.

Peakall, D.B. (1994). The role of biomarkers in environmental assessment. Ecotoxicology, 3,157-160.

Pereira, L., Fernandes, M.N., Martinez, C.B. (2013). Hematological and biochemical alterations in the fish Prochilodus lineatus caused by the herbicide clomazone. Environmental Toxicology and Pharmacology, 36, 1-8.

Pérez-Parada, A., Goyenola, G., Teixeira de Mello, F., Heinzen, H. (2018). Recent advances and open questions around pesticide dynamics and effects on freshwater fishes. Current Opinion in Environmental Science \& Health, 4, 38-44.

Perry, S.F., Jonz, M.G., Gilmour, K.M. (2009). Oxygen sensing and the hypoxic ventilatory response. In: J.G. Richards, A.P. Farrell, C.J. Brauner (Eds), Hypoxia, Fish Physiology (vol 27, pp. 194-255). Academic Press, Elsevier.

Philippe, C., Hautekiet, P., Grégoir, A.F., Thoré, E.S.J., Brendonck, L., De Boeck, G., Pinceel, T. (2019). Interactive effects of 3,4-DCA and temperature on the annual killifish Nothobranchius furzeri. Aquatic Toxicology, 212,146-153.

Philippe, C., Hautekiet, P., Grégoir, A.F., Thoré, E.S.J., Pinceel, T., Stoks, R., Brendonck, L., De Boeck, G. (2018). Combined effects of cadmium exposure and temperature on the annual killifish (Nothobranchius furzeri). Environmental Toxicology and Chemistry, 37, 2361-2371.

Pollock, M.S., Clarke, L.M.J., Dubé, M.G. (2007). The effects of hypoxia on fishes: from ecological relevance to physiological effects. Environmental Reviews, 15, 1-14.

Pörtner, H.O. (2010). Oxygen- and capacity-limitation of thermal tolerance: a matrix for integrating climate-related stressor effects in marine ecosystems. Journal of Experimental Biology, 213, 881-893.

Pullaguri, N., Grover, P., Abhishek, S., Rajakumara, E., Bhargava, Y., Bhargava, A. (2021). Triclosan affects motor function in zebrafish larva by inhibiting ache and syn2a genes. Chemosphere, 266, 128930.

Rahman, M.S. \& Thomas, P. (2018). Interactive effects of hypoxia and PCB coexposure on expression of CYP1A and its potential regulators in Atlantic croaker liver. Environmental Toxicology, 33, 411-421. 
Rantin, F.T., Kalinin, A., Monteiro, D.A. (2020). The cardiovascular system. In B. Baldisserotto, E.C. Urbinati, \& J.E.P. Cyrino (Eds.), Biology and physiology of freshwater neotropical fish (1st ed., pp. 185-216). Academic Press, Elsevier Inc.

Rantin, F.T., Kalinin, A.L., Guerra C.D.R., Maricondi-Massari, M.; Verzola, R.M.M. (1995). Electrocardiographic characterization of myocardial function in normoxic and hypoxic teleosts. Brazilian Journal of Medical and Biological Research, 28, 1277-1289.

Regan, M.D., Gill, I.S., Richards, J.G. (2017). Calorespirometry reveals that goldfish prioritize aerobic metabolism over metabolic rate depression in all but nearanoxic environments. Journal of Experimental Biology, 220, 564-572.

Regan, M.D., Mandic, M., Dhillon, R.S., Lau, G.Y., Farrell, A.P., Schulte, P.M., Seibel, B.A., Speers-Roesch, B., Ultsch, G.R., Richards, J.G. (2019). Don't throw the fish out with the respirometry water. Journal of Experimental Biology, 222, 9-10.

Rezende, E.L, Bozinovic, F. (2019). Thermal performance across levels of biological organization. Philosophical transactions of the Royal Society of London. Series B, Biological Sciences, 374, 20180549

Rezende, E.L., Castañeda, L.E., Santos, M. (2014). Tolerance landscapes in thermal ecology. Functional Ecology, 28, 799-809.

Richards, J.G. (2009). Metabolic and molecular responses of fish to hypoxia. In J.G. Richards, A.P. Farrell \& C.J. Brauner (Eds.), Fish Physiology (vol. 27, pp. 301360). Academic Press.

Rodgers, E.M. \& De Boeck, G. (2019). Nitrite-induced reductions in heat tolerance are independent of aerobic scope in a freshwater teleost. Journal of Experimental Biology, 222, jeb212035.

Rogers, N.J., Urbina, M.A., Reardon, E.E., McKenzie, D.J., Wilson, R.W. (2016). A new analysis of hypoxia tolerance in fishes using a database of critical oxygen level ( $\left.P_{\text {crit }}\right)$. Conservation Physiology, 4, cow012.

Saaristo, M., Brodin, T., Balshine, S., Bertram, M.G., Brooks, B.W., Ehlman, S.M., McCallum, E.S., Sih, A., Sundin, J., Wong, B.B.M., Arnold, K.E. (2018). Direct and indirect effects of chemical contaminants on the behaviour, ecology and evolution of wildlife. Proc. R. Soc. B 285, 20181297.

Sancho, E., Ferrando, M.D., Andreu, E. (1998). In vivo inhibition of AChE activity in the European eel Anguilla anguilla exposed to technical grade fenitrothion. Comparative Biochemistry and Physiology Part C: Pharmacology, Toxicology and Endocrinology, 120, 389-395. 
1002

1003

1004

1005

1006

1007

1008

1009

1010

1011

1012

1013

1014

1015

1016

1017

1018

1019

1020

1021

1022

1023

1024

1025

1026

1027

1028

1029

1030

1031

1032

1033

1034

1035

1036

1037

Schjolden, J., Sørensen, J., Nilsson, G.E, Poléo, A.B.S. (2007). The toxicity of copper to crucian carp (Carassius carassius) in soft water. Science of the Total Environment, 384, 239-251.

Schulte PM, Healy TM, Fangue NA. 2011. Thermal performance curves, phenotypic plasticity, and the time scales of temperature exposure. Integrative and Comparative Biology, 51, 691-702.

Schulte, P.M. (2015). The effects of temperature on aerobic metabolism: Towards a mechanistic understanding of the responses of ectotherms to a changing environment. Journal of Experimental Biology, 218, 1856-1866.

Shingles, A., McKenzie, D.J., Taylor, E.W., Moretti, A., Butler, P.J., Ceradini, S. (2001). Effects of sublethal ammonia exposure on swimming performance in rainbow trout (Oncorhynchus mykiss). Journal of Experimental Biology, 204, 2691-2698.

Shiogiri, N.S., Paulino, M.G., Carraschi, S.P, Baraldi, F.G., Cruz, C., Fernandes, M.N. (2012). Acute exposure of a glyphosate-based herbicide affects the gills and liver of the Neotropical fish, Piaractus mesopotamicus. Environmental Toxicology and Pharmacology, 34, 388-396.

Sokolova, I.M. \& Lannig, G. (2008). Interactive effects of metal pollution and temperature on metabolism in aquatic ectotherms: implications of global climate change. Climate Research, 37, 181-201.

Speranza, E.D., Colombo, M., Tatone, L.M., Cappelletti, N., Migoya, M.C., Colombo, J.C. (2016). Fatty acid alterations in the detritivorous Prochilodus lineatus promoted by opportunistic feeding on sewage discharges in the Río de la Plata estuary. Journal of Fish Biology, 89, 2024-2037.

Spinks RK, Munday PL, Donelson JM. 2019. Developmental effects of heatwave conditions on the early life stages of a coral reef fish. J Exp Biol 222:jeb202713.

Sprague, J.B. (1971). Measurement of pollutant toxicity to fish III: Sublethal effects and "safe" concentrations. Water Research, 5, 245-266.

Stauffer, J. (1998). The water crisis: Constructing solutions to freshwater pollution. London: Earthscan.

Stieglitz, J.D., Mager, E.M., Hoenig, R.H., Benetti, D.D., Grosell, M. (2016). Impacts of Deepwater Horizon crude oil exposure on adult mahi-mahi (Coryphaena hippurus) swim performance. Environmental Toxicology and Chemistry, 35, 2613-2622.

Stillman, J.H. (2019). Heat waves, the new normal: Summertime temperature extremes will impact animals, ecosystems, and human communities. Physiology, 34, 86100. 
Suresh, A., Sivaramakrishna, B., Victoriamma, P.C., Radhakrishnaiah, K. (1992). Comparative study on the inhibition of acetylcholinesterase activity in the freshwater fish Cyprinus carpio by mercury and zinc. Biochemistry International, 26, 367-375.

Takle, J.C.C., Beitinger, T.L., Dickson, K.L. (1983). Effect of the aquatic herbicide endothal on the critical thermal maximum of red shiner, Notropis lutrensis. Bulletin of Environmental Contamination and Toxicology, 31, 512-517.

Thomas, J.K. \& Janz, D.M. (2011). Dietary selenomethionine exposure in adult zebrafish alters swimming performance, energetics and the physiological stress response. Aquatic Toxicology, 102, 79-86.

Thomaz, J.M., Martins, N.D., Monteiro, D.A., Rantin, F.T., Kalinin, A.L. (2009). Cardiorespiratory function and oxidative stress biomarkers in Nile tilapia exposed to the organophosphate insecticide trichlorfon (NEGUVON®). Ecotoxicology Environmental Safety, 72, 1413-1424.

Tierney, K., Casselman, M., Takeda, S., Farrell, T., Kennedy, C. (2007). The relationship between cholinesterase inhibition and two types of swimming performance in chlorpyrifos-exposed coho salmon (Oncorhynchus kisutch). Environmental Toxicology and Chemistry, 26, 998-1004.

Tudorache, C., Blust, R., De Boeck, G. (2008). Social interactions, predation behaviour and fast start performance are affected by ammonia exposure in brown trout (Salmo trutta L.). Aquat. Toxicol. 90, 145-153.

Ultsch, G.R., Regan, M.D. (2019). The utility and determination of Pcrit in fishes. Journal of Experimental Biology, 222, 1-9.

van der Oost, R., Beyer, J., Vermeulen, N.P.E. (2003). Fish bioaccumulation and biomarkers in environmental risk assessment: a review. Environmental Toxicology and Pharmacology, 13, 57-149.

van der Oost, R., McKenzie, D.J., Verweij, F., Satumalay, C., van der Molen, N., Winter, M.J., Chipman, J.K. (2020). Identifying adverse outcome pathways (AOP) for Amsterdam city fish by integrated field monitoring. Environmental Toxicology and Pharmacology, 74, 103301.

Wagner, M. \& Lambert, S. (2018). Microplastics are contaminants of emerging concern in freshwater environments: An overview. In: M. Wagner \& S. Lambert (Eds.), Freshwater microplastics. emerging environmental contaminants (pp 1-24). The Handbo. Springer Open. p 1-24.

Wang, T., Lefevre, S., Iversen, N.K., Findorf, I., Buchanan, R., McKenzie, D.J. (2014). Anaemia only causes a small reduction in the upper critical temperature of sea 

bass: is oxygen delivery the limiting factor for tolerance of acute warming in fishes? Journal of Experimental Biology, 217, 4275-4278.

Wang, Z., Kwok, K.W., Leung, K.M. (2019). Comparison of temperate and tropical freshwater species' acute sensitivities to chemicals: An update. Integrated Environmental Assessment and Management, 15, 352-363.

Wang, H., Liang, Y., Li, S., Chang, J. (2013). Acute toxicity, respiratory reaction, and sensitivity of three cyprinid fish species caused by exposure to four heavy metals. PLOS ONE, 8, e65282.

Watenpaugh, D.E., Beitinger, T.L., Huey, D.W. (1985). Temperature tolerance of nitriteexposed catfish. Transactions of the American Fisheries Society, 114, 274-278.

Williams, C.M., Buckley, L.B., Sheldon, K.S., Vickers, M., Pörtner, H.O., Dowd, W.W., Gunderson, A.R., Marshall, K.E., Stillman, J.H. (2016). Biological impacts of thermal extremes: mechanisms and costs of functional responses matter. Integrative and Comparative Biology, 56, 73-84.

Wood, A.W., Johnston, B.D., Farrell, A.P., Kennedy, C.J. (1996). Effects of didecyldimethylammonium chloride (DDAC) on the swimming performance, gill morphology, disease resistance, and biochemistry of rainbow trout (Oncorhynchus mykiss). Canadian Journal of Fisheries and Aquatic Sciences, 53, 2424-2432.

Wood, CM. (2018). The fallacy of the Pcrit - Are there more useful alternatives? Journal of Experimental Biology, 221, jeb163717

Xia, J.G., Nie, L.J., Mi, X.M., Wang, W.Z., Ma, Y.J., Cao, Z.D., Fu, S.J. (2015). Behavior, metabolism and swimming physiology in juvenile Spinibarbus sinensis exposed to PFOS under different temperatures. Fish Physiology Biochemistry, 41, 1293-1304.

Yang, R., Brauner, C., Thurston, V., Neuman, J., Randall, D. (2000). Relationship between toxicant transfer kinetic processes and fish oxygen consumption. Aquatic Toxicology, 48, 95-108.

Zebral, Y.D., Lansini, L.R., Costa, P.G., Roza, M., Bianchini, A., Robaldo, R.B. (2018). A glyphosate-based herbicide reduces fertility, embryonic upper thermal tolerance and alters embryonic diapause of the threatened annual fish Austrolebias nigrofasciatus. Chemosphere, 196, 260-269. 


\section{Figure Legends}

1108 Figure 1. Reduced tolerance of hypoxia, as measured by critical oxygen level $\left(\mathrm{O}_{2 c r i t}\right)$, in

1109 matrinxã Brycon amazonicus, after exposure to various different pollutants. $\mathrm{Ct}=$ control 1110 condition, MP = methyl parathion, $\mathrm{Hg}=\mathrm{HgCl}_{2}, \mathrm{TC}=$ triclosan, $\mathrm{RT}=$ Roundup Transorb, 1111 RO = Roundup Original, RWG = Roundup WG. (Adapted from: Olle, 2007; Anelli Jr., 1112 2010; Monteiro et al., 2013; Martins, 2018).

1113 Figure 2. Influence of ambient oxygenation on oxygen uptake rate $\left(\dot{M} \mathrm{O}_{2}\right)$ of matrinxã 1114 Brycon amazonicus, after exposure to various different pollutants. $\mathrm{Ct}=$ control, $\mathrm{MP}=$ 1115 methyl parathion, $\mathrm{Hg}=\mathrm{HgCl}_{2}, \mathrm{TC}=$ triclosan, $\mathrm{RT}=$ Roundup Transorb, $\mathrm{RO}=$ Roundup 1116 Original, RWG = Roundup WG. Closed symbols denote a significant difference in relation 1117 to the normoxic values $(P<0.05)$. (Adapted from: Olle, 2007; Anelli Jr., 2010; Monteiro 1118 et al., 2013; Martins, 2018).

1119 Figure 3. The relationship of acclimation temperature to thermal safety margin (TSM) in 1120 subtropical and tropical freshwater fishes, where TSM is the difference, in ${ }^{\circ} \mathrm{C}$, between 1121 acclimation $\mathrm{T}$ and $\mathrm{CT}_{\max }$. Open symbols, control conditions for all data carried in Table 1122 2. Grey symbols, conditions where contaminants caused a significant decline in $\mathrm{CT}_{\max }$.

1123 Based upon data from 14 studies on 12 species exposed to 15 contaminants (Table 2). 1124 Control data, dashed line, $R^{2}=0.828, P<1 \times 10^{-8}$, exposed data, dotted line, $R^{2}=0.716$, $1125 P<1 \times 10^{-5}$. Slopes are not significantly different $(P=0.129$, two-way T-Test).

1126 Figure 4. Relationship between acclimation temperature $\left(T_{\mathrm{acc}}\right)$ and the extent, as a 1127 percentage of control conditions, to which contaminants decrease thermal safety 1128 margin (TSM) in sub-tropical and tropical freshwater fishes. Data are taken from Table 11292 , for all those situations where contamination caused a significant decline in $\mathrm{CT}_{\max }$ ( $\mathrm{n}$ $1130=17$, from 11 studies of 11 contaminants on 10 species). Line describes a linear 1131 regression, dotted lines are $95 \%$ confidence intervals, $R^{2}=0.43, P=0.0012$. This 1132 figure is based upon a very limited dataset and should, therefore, be interpreted with 1133 caution until the knowledge base is extended (see main text for details) 


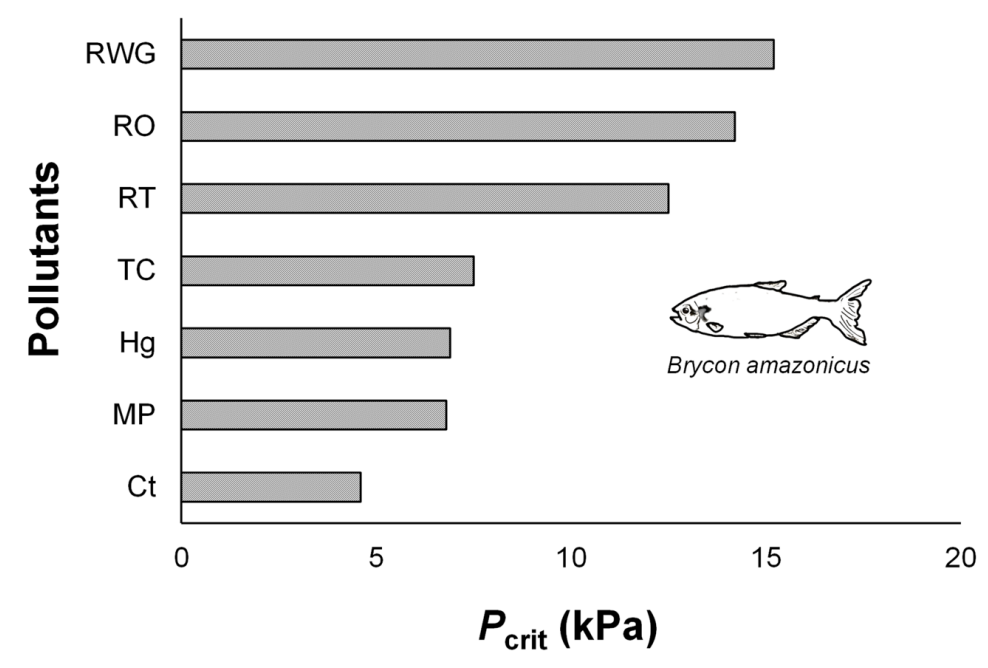

1135

1136 


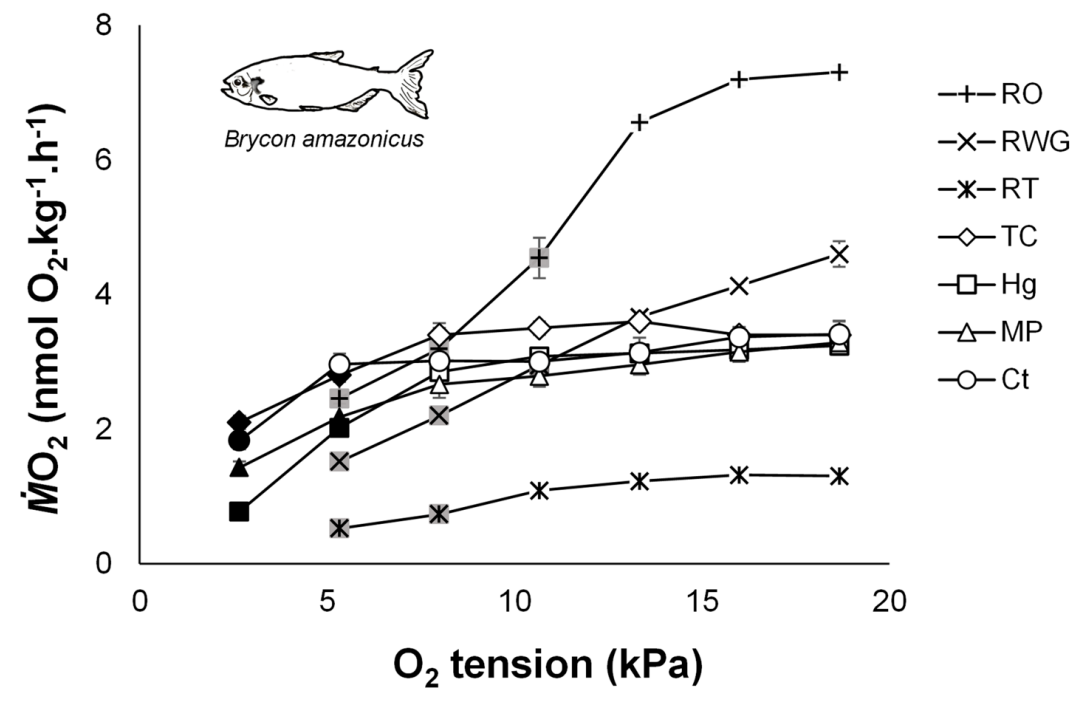

1137

1138 


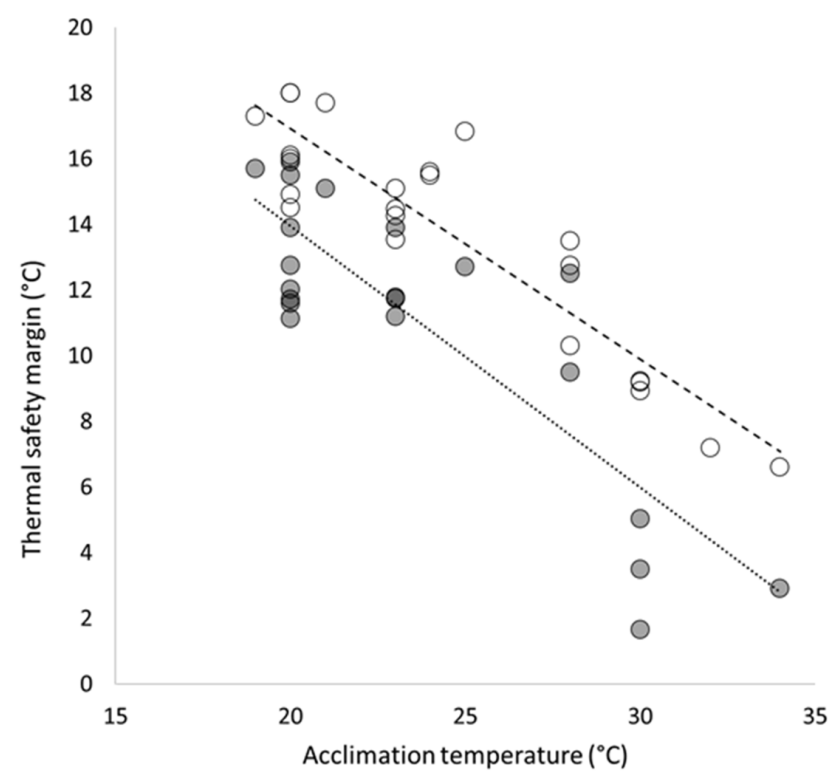

1139

1140 


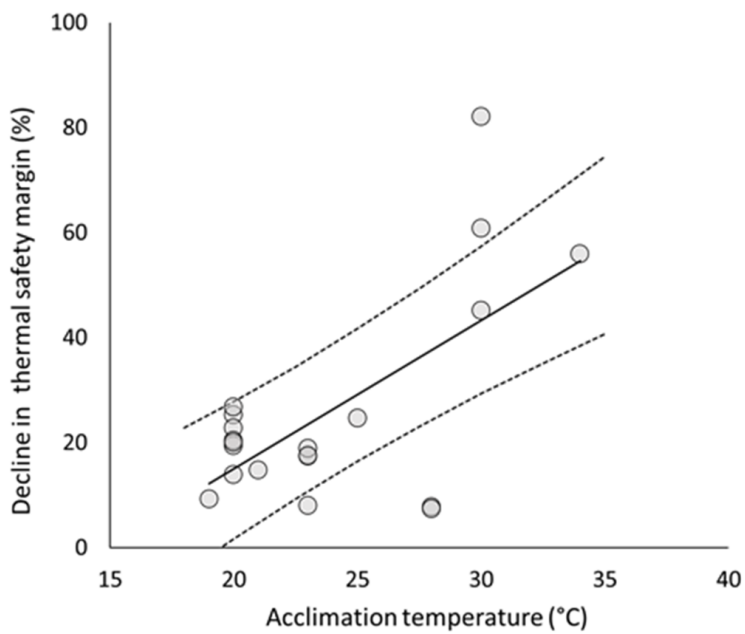

1141

1142 


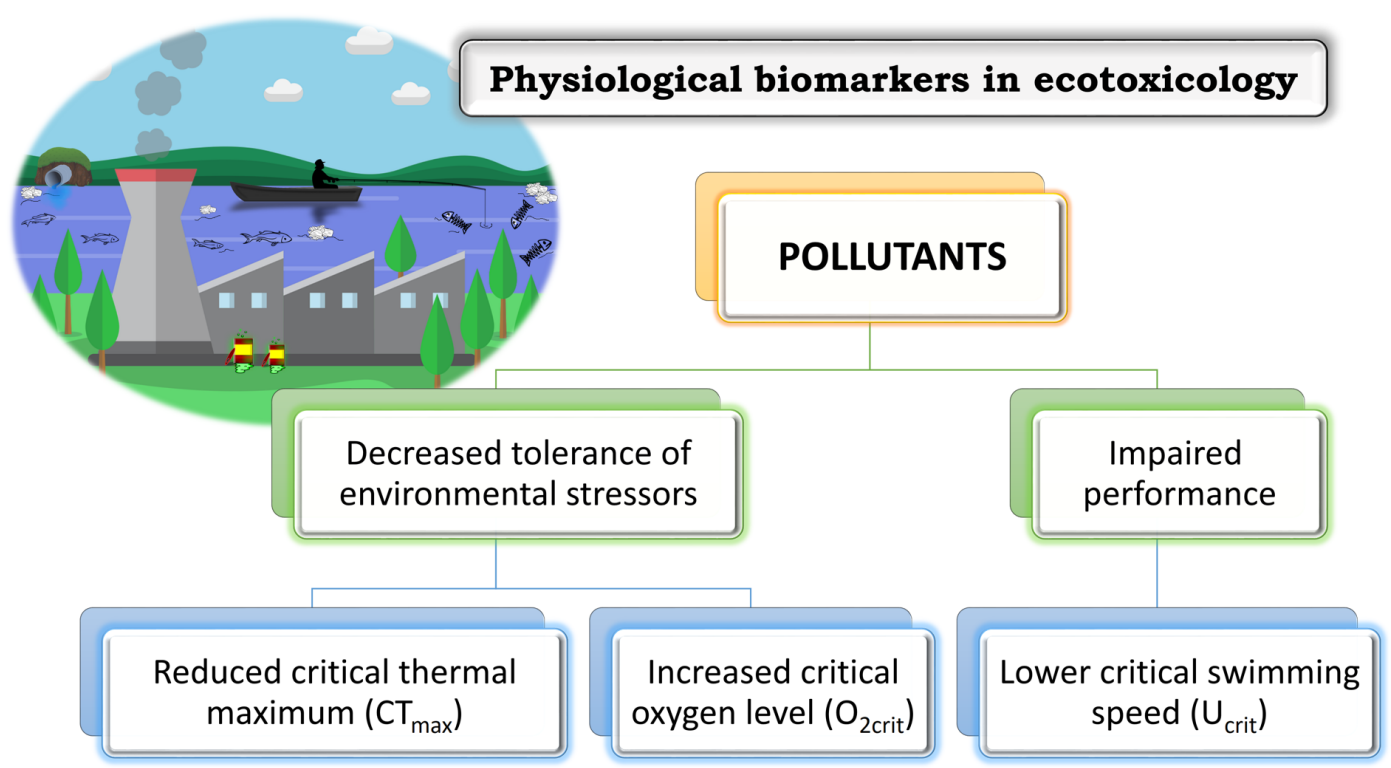

